\title{
Factors Related to Work Stress among Health Office Employees during Covid-19 Pandemic
}

\author{
Faktor yang Berhubungan dengan Stres Kerja pada Pekerja Dinas Kesehatan di \\ Masa Pandemi COVID-19
}

\author{
Luga Rizqi Cristenzein, Kadek Tresna Adhi \\ Bachelor of Public Health Study Program, Faculty of Medicine, Udayana University \\ Jalan P.B. Sudirman, Denpasar, Bali, 80232 Indonesia
}

\begin{abstract}
Introduction: Study related to work stress is usually more focused on the industrial sector. Meanwhile, workers in other sectors such as the government organization also have the potential to feel stressed due to their job. During the COVID-19 (Coronavirus Disease) pandemic, Health Office is one of the main stakeholders in handling and preventing COVID-19. The COVID-19 pandemic can cause work stress due to unachieved health programs and huge demands to develop programs related to this pandemic. This study analyzed the relationship between individual factors, work factors, and factors outside of work with level of work stress among Health Office employees. This study is expected to be able to analyze work stress and its determinant as early as possible. Methods: This study was a cross-sectional study using the Depression, Anxiety, Stress Scale 42 (DASS-42) and NIOSH (National Institute for Occupational Safety and Health) Generic Job Stress Questionnaire instrument. This study was conducted at the Public Health Office Bogor Regency April 2021. This study used total sampling method on employees of the Public Health Office Bogor Regency with total sample collected of 135 respondents. Data analysis in this study was performed using multiple logistic regression. Results: $86.67 \%$ of respondents did not experience work stress, $5.93 \%$ of respondents had mild work stress, and $7.41 \%$ of respondents experienced moderate work stress. Moreover, workload $(p=0.0001)$ and social support $(p=0.011)$ had a significant relationship in increasing work stress. Conclusion: Workload was the most dominant variable affecting work stress in which workers who had high subjective workload were 33.63 times more stressful compared to workers who had the appropriate workload. Prevention of occupational stress can be done by adjusting workloads and building a good social environment between colleagues.
\end{abstract}

Keywords: factors outside of work, health office, individual factors, work factors, work stress

\begin{abstract}
ABSTRAK
Pendahuluan: Penelitian yang sering dilakukan terkait stres kerja biasanya lebih memfokuskan kepada bidang industri. Padahal, pekerja di bidang lain seperti bidang pemerintahan juga berpotensi mengalami stres akibat pekerjaan. Dinas Kesehatan merupakan salah satu stakeholder utama dalam penanganan dan pencegahan COVID-19. Pandemi COVID - 19 dapat menyebabkan stres kerja akibat target program kesehatan yang tidak tercapai serta tuntutan untuk menyusun program penanganan dan pencegahan COVID-19. Penelitian ini menilai hubungan antara faktor individu, faktor pekerjaan, dan faktor di luar pekerjaan dengan stres kerja di Dinas Kesehatan Kabupaten Bogor. Metode: Penelitian ini adalah penelitian cross-sectional yang menggunakan instrument Depression, Anxiety, Stres Scale 42 (DASS-42) dan NIOSH Generic Job stres Questionnaire. Penelitian ini dilakukan di Dinas Kesehatan Kabupaten Bogor pada bulan April 2021. Penelitian ini menggunakan metode total sampling pada pegawai Dinas Kesehatan Kabupaten Bogor dengan jumlah sampel terkumpul sebanyak 135 responden. Analisis data pada penelitian ini dilakukan dengan regresi logistik berganda. Hasil: $86,67 \%$ responden tidak mengalami stres kerja, 5,93\% responden stres kerja ringan, dan 7,41\% responden mengalami stres kerja sedang. Beban kerja $(p=0,0001)$ dan dukungan sosial $(p=0,011)$ berhubungan signifikan dalam meningkatkan stres kerja. Simpulan: Beban kerja merupakan variabel yang paling dominan mempengaruhi stres kerja dengan 33,63 kali lebih meningkatkan stres kerja dibandingkan dengan pekerja yang memiliki beban kerja sesuai. Pencegahan stres kerja dapat dilakukan dengan penyesuian beban kerja serta membangun lingkungan sosial yang baik antar rekan kerja.
\end{abstract}

Kata kunci: dinas kesehatan, faktor di luar pekerjaan, faktor individu, faktor pekerjaan, stres kerja 


\section{Corresponding Author:}

Kadek Tresna Adhi

Email: ktresnaadhi@unud.ac.id

Telephone: +6281236288867

\section{INTRODUCTION}

There are several kinds of stress that can be caused by the Coronavirus Disease-19 (COVID-19) pandemic, which are academic stress experienced by students, work stress experienced by workers, and stress in the family (Lutfida, 2020). In fact, work stress is not a new phenomenon, yet it still becomes a threat to the healthiness and well-being of workers. Work stress can be defined as harmful physical and emotional responses due to incompatability between work, abilities, resources, and worker needs (Lady, Susihono and Muslihati, 2017). The Health and Safety Executive survey in 2017 - 2018 showed that stress and depression related to work reached 595,000 cases with 1,800 cases in every 100,000 workers (Health \& Safety Executive, 2018).

Studies related to occupational stress are usually more focused on the industrial sector. Meanwhile, workers in other sectors such as government organization may also experience stress related to work (Reppi, Sumampouw and Lestari, 2020). In fact, job activities in government organizations that count heavily on brain abilities will cause work to become more diverse and increase work stress (Jundillah et al., 2017). A study related to work stress in government organizations, especially in Health offices, showed that there were different levels of work stress that could be experienced by workers. Sorongan, Suoth and Boky (2018) found that 27.7\% workers at the Manado Health Office experienced mild work stress while another $72.3 \%$ experienced moderate work stress. Unfortunately, this study has not explored the factors that cause stress among Health Office employees more comprehensively.

As one of the main government stakeholders in handling and preventing COVID-19, it takes hard work and quick work from all employess in the Health Office at this pandemic era (Akbar, 2020). Furthermore, pandemic has forced several changes in health programs to adjust with this pandemic situation. How a country deals with COVID-19 pandemic situation will also bear a heavy share of the burden among workers (Sinclair et al., 2020). This kind of situation would increase job demands which could cause burnout symptoms such as boredom and work stress (Nugroho, 2021). This study is, therefore, expected to be able to analyze work stress and its determinants among Health Office workers as one of the government organizations as early as possible. Thus, appropriate and effective prevention strategies can be carried out to overcome work stress, especially during this COVID-19 pandemic. Work stress that is successfully able to overcome is expected to increase worker productivity in providing public services in the health sector and help workers to be able to objectify health programs that have been planned in order to improve public health status under the jurisdiction of the Health Office itself.

\section{METHODS}

This research was a cross-sectional quantitative study conducted at the Public Health Office Bogor Regency during April 2021 using 2 standard instruments, namely Depression, Anxiety, Stress Scale 42 (DASS-42) to measure work stress levels and the National Institute for Occupational Safety and Health (NIOSH) Generic Job Stress Questionnaire to analyze the determinants of the work stress itself. This study used a total sampling method from accessible populations of 145 employees. After distributing the instruments, the number of samples obtained was 135 employees. The conditions that made some employess unable to fill out the instruments were work mutations, illnesses, unpaid leave, and unwillingness to become respondents. However, the number of samples obtained has already met the minimum sample size which could be calculated by a hypothesis test for two population proportions from the proportion of work stress among workers with inappropriate and appropriate workloads based on the result of previous study. The result of this test showed that the minimum sample size was 57 respondents, so that the sample that had been obtained could be generalized.

The two instruments that were used in this study had been tested for their validity and reliability. DASS-42 showed $r$ value $>r$ table $(0.361)$ on all statements in the Pearson Product Moment Test and had an alpha coefficient of 0.879 , so it could be declared valid (Sedana, 2018). Meanwhile, NIOSH Generic Job Stress Questionnaire was considered valid and reliable because it had been validated by several researchers for uses in various types of jobs with a validity value of $0.68-0.91$ and a short rating scale with reliability of 0.53 in Indonesia (Hasanah, Rahayuwati and Yudianto, 2020). This study used 
several variables that could be measured by NIOSH Generic Job Stres Questionnaire, which were age, sex, work period, personality type, physical environment, career development, role conflict, interpersonal conflict, workload, social support, and non-work activities.

Data in this study consisted of primary data and secondary data. Primary data were obtained through online questionnaires filled out by the employees and interview, while secondary data were obtained from the database of the Public Health Office Bogor Regency. Primary data that had been collected were analyzed to determine the correlation between independent variables and work stress as well as the most dominant variables affecting it. Data analysis in this study was performed using multiple logistic regression. The scoring results of the DASS-42 instruments categorized stress into 5 categories, which were no work stress, mild work stress, moderate work stress, severe work stress, and very severe work stress. However, in the correlation analysis between factors and work stress in this study, these categories were divided into two groups, which were no work stress and work stress. Thus, the results of the study showed what factors were related to work stress without considering the level.

Before entering the multiple logistic regression, a chi-square test was carried out to analyze the independent correlation between independent variables and work stress. Chi-square test was also performed as a selection of predictor variables for multiple logictic regression analysis. Only variables with $\mathrm{p}$ value $<0.20$ were included in the multiple logistic regression analysis model. This study has Ethical Clearence No. 2021.01.1.0591 from the Ethical Committee of the Medical Faculty of Udayana University.

\section{RESULTS}

\section{Work Stress}

Work stress levels were categorized into 5 categories according to the score obtained when filling out the DASS-42 instruments. No work stress (scoring 0-14), mild work stress (scoring 15-18), moderate work stress (scoring 19-25), severe work stress (scoring 26-33), and very severe work stress (scoring $>33$ ). The results showed that employees did not experience severe to very severe work stress. The results showed that 117 respondents $(86.67 \%)$ did not experience work stress, 8 respondents
$(5.93 \%)$ had a mild level of work stress, and 10 respondents $(7.41 \%)$ experienced a moderate level of work stress.

\section{Work Stress Complaints during the Pandemic}

This study compared the level of stress complaints felt by workerks during the pandemic with that before the pandemic. Data were obtained from 3 additional questions on the instrument to determine the subjective feelings of workers related to stress complaints. The results showed that $33 \%$ of workers admitted that the pandemic made them feel stressed when doing work, $19 \%$ of workers claimed to have experienced complaints before the pandemic, and $25 \%$ of workers admitted that their complaints were getting worse when doing work during the pandemic. However, this study did not specifically analyze the correlation between work stress and the COVID-19 pandemic.

\section{Individual Factors of Respondents}

This study used several variables to determine the individual factors of workers, which were age, sex, work period, and personality type.

\section{Age}

In this study, the age of the respondents was divided into 2 categories based on Hurlock's theory of early and middle adulthood, which were $\leq 40$ years old (early adulthood) and $>40$ years old (middle adulthood). Early adulthood is described as a time of seeking stability, having full of problems,

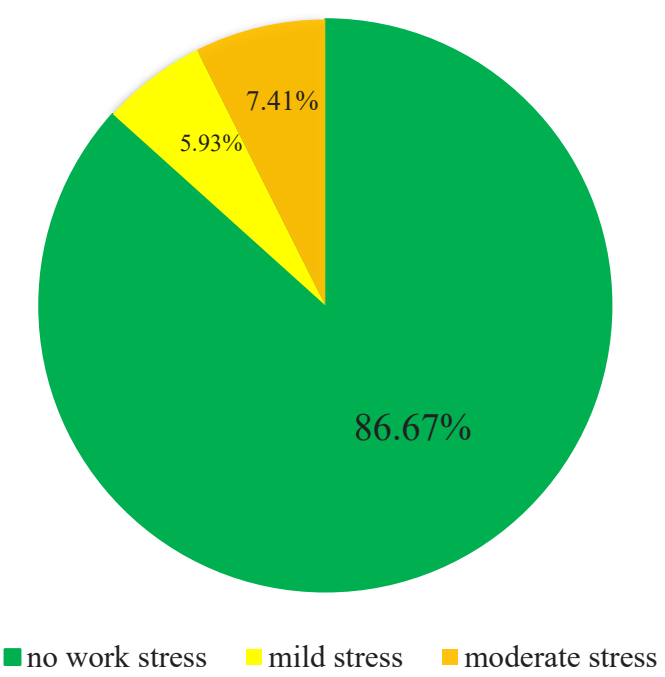

Figure 1. Work Stress Levels of Respondents at the PublicHealth Office Bogor Regency in 2021 


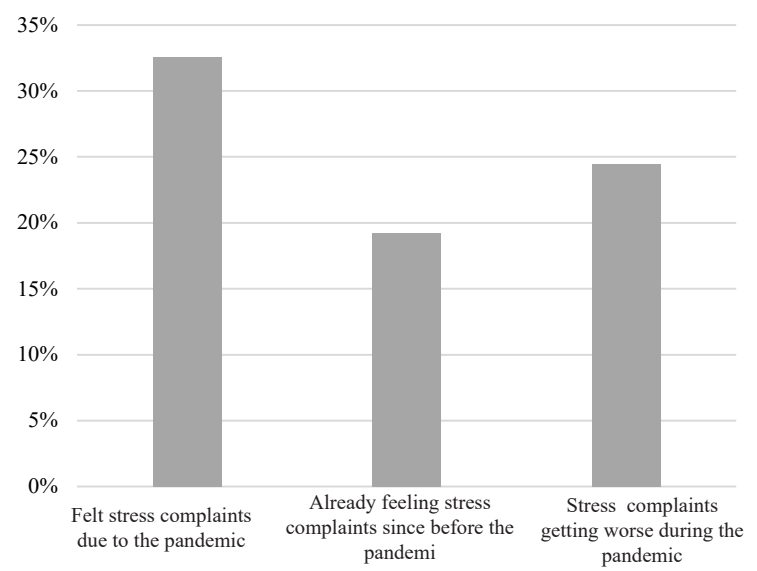

Figure 2. Stress Complaints Before and During the Pandemic

having emotional tension, and having adjustment to a new lifestyle. Meanwhile, middle adulthood is described as a transitional period which leads to several changes in behavior and social characteristics from early adulthood to a new period in life with new behavior and social characteristics (Peristianto, 2021). Based on the results obtained, the majority of respondents were aged $>40$ years old $(60.74 \%)$, while the rest were $\leq 40$ years old $(39.26 \%)$ with an average age of 42 years old.

\section{Sex}

Two-thirds of the respondents in this study were female workers. It means that the number of male workers was fewer than that of female workers.

Table 1. The Distribution of Individual Factors of Respondents at the Public Health Office Bogor Regency in 2021

\begin{tabular}{lcc}
\hline $\begin{array}{l}\text { I n d i v i d u a l } \\
\text { Factors }\end{array}$ & Frequency (n) & Percentage (\%) \\
\hline Age & & \\
$\leq 40$ years old & 53 & 39.26 \\
$>40$ years old & 82 & 60.74 \\
Sex & & \\
Female & 90 & 66.67 \\
Male & 45 & 33.33 \\
Work Period & & \\
$\leq 10$ years & 56 & 41.48 \\
$>10$ years & 79 & 58.52 \\
Personality Type & & \\
Type A & 69 & 51.11 \\
Type B & 66 & 48.89 \\
\hline
\end{tabular}

\section{Work Period}

Work period in this study was categorized into 2 groups by considering the data distribution. Since the respondents had an average of 13 years work period, then the work period in this study was categorized into $>10$ years work period and $\leq$ 10 years work period. The results showed that the majority of respondents had been working for $>10$ years $(58.52 \%)$.

\section{Personality Type}

A personality type is a person's pattern of behavior. In this study, personality types were divided into 2 types, which was type A and type B. Individuals with personality type A were known to be more aggressive and ambitious than individuals with personality type $\mathrm{B}$ who tended to be more relaxed (Astuti, 2018). Personality types were categorized based on the mean score because the data were normally distributed. The results showed that more than half of the respondents had type A personality $(51.11 \%)$.

\section{Work Factors of Respondents}

Work factors that were used in this study were the physical environment, career development, role conflict, interpersonal conflict, and workload.

\section{Physical Environment}

Physical environment is the perception of workers on the physical condition of while they work. In this study, data on this variable were not normally distributed, so they were categorized into poor and good based on the median score. The results showed that 69 respondents $(51.11 \%)$ considered their work environment good while the other 66 respondents $(48.89 \%)$ considered their work environment poor.

\section{Career Development}

Career development refers to the oppurtunities that employees have to develop their careers in the next few years. Data on this variable were normally distributed, so they were categorized based on the mean score. The results showed that the majority of respondents $(50.37 \%)$ did not have good career development. 
Table 2. The Distribution of Work Factors of Respondents at the Public Health Office Bogor Regency in 2021

\begin{tabular}{lcc}
\hline \multicolumn{1}{c}{ Work Factors } & Frequency (n) & Percentage (\%) \\
\hline Physical Environtment & & \\
Poor & 66 & 48.89 \\
Good & 69 & 51.11 \\
Career Development & & \\
Poor & 68 & 50.37 \\
Good & 67 & 49.63 \\
Role Conflict & & \\
High & 70 & 51.85 \\
Low & 65 & 48.15 \\
Interpersonal Conflict & & \\
High & 76 & 56.30 \\
Low & 59 & 43.70 \\
Workload & & \\
High & 71 & 52.59 \\
Appropriate & 64 & 47.41 \\
\hline
\end{tabular}

\section{Role Conflict}

Role conflict is a conflict that appears when respondents try to fit several roles all at once. In this study, this variable was categorized into high and low based on the median score because the data were not normally distributed. More than a half of the respondents $(51.85 \%)$ felt high level of role conflict while doing their job.

\section{Interpersonal Conflict}

Interpersonal conflict is the respondent's conflict with his/her colleagues due to personal dislike. Since the data on this variable were not normally distributed, the data were categorized into high or low based on the median value. The results showed that the majority of respondents $(56.30 \%)$ had a high level of interpersonal conflict at work.

\section{Workload}

In this study, workload refers to subjective feelings related to job demands and responsibilities owned by the respondents. Data on this varable were not normally distributed, so they were divided into high and appropriate amount of workload based on the median score. It turns out that most of respondents $(52.59 \%)$ felt they had a high amount of workload, while the rest of them $(47.41 \%)$ felt they had appropriate amount of workload.
Table 3. The Distribution of Factors Outside of Works of Respondents at the Public Health Office Bogor Regency in 2021

\begin{tabular}{lcc}
\hline $\begin{array}{l}\text { Factors Outside } \\
\text { of Work }\end{array}$ & Frequency (n) & Percentage (\%) \\
\hline Non-work Activities & & \\
High & 89 & 65.93 \\
Low & 46 & 34.07 \\
Social Support & & \\
Good & 61 & 45.19 \\
Poor & 74 & 54.81 \\
\hline
\end{tabular}

\section{Factors Outside of the Respondents' Work}

There were two variables analyzed on factors outside of work, which were non-work activities and social support.

\section{Non-work Activities}

Non-work activites refer to the activities that are carried out by the respondents outside of their working hours and are unrelated to their job. These activities could be another job, educational activities, responsibility for taking care of other family members, house chores, voluntary organizations, and religious activities. In this study, non-work activities were divided into high and low based on the mean score because the data were normally distributed. The results showed that more than a half of the respondents $(65.93 \%)$ had high activities outside of work.

\section{Social Support}

In this study social support is defined as emotional support, appraisal support, informational support, and instrumental support obtained by the respondents from their social networks. Data on this variable were divided into good and poor based on the median score because they were not normally distributed. The results showed that most of the respondents $(54.81 \%)$ had received good social support from their social networks, while the rest $(45.19 \%)$ did not receive it.

\section{The Correlation between Individual Factors and Work Stress}

The results of this study showed that the proportion of work stress was found to be greater among respondents aged over 40 years old, male workers, respondents with over a 10 -year work 
Table 4. The Correlation between Respondents' Individual Factors and Work Stress at the Public Health Office Bogor Regency in 2021

\begin{tabular}{lccc}
\hline \multirow{2}{*}{\begin{tabular}{c} 
I n d i v i d u a $\mathbf{~}$ Factors \\
\cline { 2 - 3 }
\end{tabular}} & Stress (\%) & $\begin{array}{c}\text { Not Stress } \\
(\mathbf{\%})\end{array}$ & \\
\hline Age & & & \\
$\leq 40$ years old & $10(18.87)$ & $43(81.13)$ & 0.13 \\
$>40$ years old & $8(9.76)$ & $74(90.24)$ & \\
Sex & & & \\
Female & $10(11.11)$ & $80(88.89)$ & 0.29 \\
Male & $8(17.78)$ & $37(82.22)$ & \\
Work Period & & & \\
$\leq 10$ years & $7(12.50)$ & $49(87.50)$ & 0.81 \\
$>10$ years & $11(13.92)$ & $68(86.08)$ & \\
Personality Type & & & \\
Type A & $12(17.39)$ & $57(82.61)$ & 0.16 \\
Type B & $6(9.09)$ & $60(90.91)$ & \\
\hline
\end{tabular}

period, and respondents with personality type A. However, none of these variables had significant independent correlation with work stress based on the results of chi-square test $(p>0.05)$. Out of these individual factors, age and personality type were eligible to be included into the multiple logistic regression analysis $(\mathrm{p}<0.20)$.

\section{The Correlation between Work Factors and Work Stress}

Regarding the work factors, the proportion of work stress was greater among respondents who worked in poor physical environment condition, respondents with poor career development, respondents with high level of role conflict and interpersonal conflict, and respondents with high subjective workload. The results of chi square test showed that only workload that had significant independent correlation with work stress $(\mathrm{p}<0.05)$. Workload was also the only variable in this work factor category that was eligible to be included into the multiple logistic regression analysis $(p<0.20)$.

\section{The Correlation between Factors Outside of Work and Work Stress}

The proportion of work stress was found to be greater among respondents with low nonwork activities and respondents with poor social support. The results of chi square test showed that neither of two variables had significant independent
Table 5. The Correlation between Respondents' Work Factors and Work Stress at the Public Health Office Bogor Regency in 2021

\begin{tabular}{lccc}
\hline \multirow{2}{*}{ Work Factors } & \multicolumn{2}{c}{ Work Stress } & \multirow{2}{*}{ P } \\
\cline { 2 - 3 } & Stress (\%) & $\begin{array}{c}\text { Not Stress } \\
(\%)\end{array}$ & \\
\hline Physical Environtment & & \\
Poor & $8(12.12)$ & $58(87.88)$ & 0.69 \\
Good & $10(14.49)$ & $59(85.51)$ & \\
Career Development & & \\
Poor & $8(11.76)$ & $60(88.24)$ & 0.59 \\
Good & $10(14.93)$ & $57(85.07)$ & \\
Role Conflict & & & \\
High & $11(15.71)$ & $59(84.29)$ & 0.40 \\
Low & $7(10.77)$ & $58(89.23)$ & \\
Interpersonal Conflict & \\
High & $11(14.47)$ & $65(85.83)$ & 0.66 \\
Low & $7(11.86)$ & $52(88.14)$ & \\
Workload & & \\
High & $17(23.94)$ & $54(76.06)$ & 0.0001 \\
Appropriate & $1(1.56)$ & $63(98.44)$ & \\
\hline
\end{tabular}

Table 6. The Correlation between Factors Outside of Work of Respondentsand Work Stress at the Bogor Regency Health Office in 2021

\begin{tabular}{lccc}
\hline \multirow{2}{*}{$\begin{array}{c}\text { Factors Outside } \\
\text { of Work }\end{array}$} & \multicolumn{2}{c}{ Work Stress } & \\
\cline { 2 - 3 } & \multicolumn{1}{c}{ Po) } & $\begin{array}{c}\text { Not Stress } \\
(\%)\end{array}$ & \\
\hline Non-work Activities & & \\
Low & $11(12.36)$ & $78(87.64)$ & 0.64 \\
High & $7(15.22)$ & $39(84.78)$ & \\
Social Support & & & \\
Poor & $11(18.03)$ & $50(81.97)$ & 0.14 \\
Good & $7(9.46)$ & $67(90.54)$ & \\
\hline
\end{tabular}

relationship with work stres ( $\mathrm{p}>0.05$ ). Out of factors outside of work, social support was eligible to be included into the multiple logistic regression analysis $(\mathrm{p}<0.20)$.

\section{Determinants Related to Work Stress}

Based on the final model of multiple logistic regression analysis, workload and social supports had significant correlation with work stress $(\mathrm{p}<0.05)$. The results also showed that workload was the most dominant variable affecting work stress with adjusted $\mathrm{OR}=33.63$ and $\mathrm{p}$ value $=0.001$. This means that high subjective workload was 33.63 
Table 7. Analysis of Determinants Related to Work Stress at the Public Health Office Bogor Regency in 2021

\begin{tabular}{|c|c|c|c|c|}
\hline \multirow{3}{*}{ Variable } & \multirow{3}{*}{$\begin{array}{c}\text { Adjusted } \\
\text { OR }\end{array}$} & \multicolumn{2}{|c|}{ Final Model } & \multirow{3}{*}{$\mathbf{P}$} \\
\hline & & \multicolumn{2}{|c|}{$95 \%$ CI } & \\
\hline & & Lower & Upper & \\
\hline \multicolumn{5}{|c|}{ Age (Years Old) } \\
\hline$\leq 40$ & \multirow{2}{*}{2.02} & \multirow{2}{*}{0.65} & \multirow{2}{*}{6.32} & \multirow{2}{*}{0.225} \\
\hline$>40$ & & & & \\
\hline \multicolumn{5}{|c|}{ Personality Type } \\
\hline Type A & \multirow{2}{*}{1.007} & \multirow{2}{*}{0.30} & \multirow{2}{*}{3.37} & \multirow{2}{*}{0.99} \\
\hline Type B & & & & \\
\hline \multicolumn{5}{|l|}{ Workload } \\
\hline High & \multirow{2}{*}{33.63} & \multirow{2}{*}{3.93} & \multirow{2}{*}{287.75} & \multirow{2}{*}{$0.001 *$} \\
\hline Low & & & & \\
\hline \multicolumn{5}{|c|}{ Social Support } \\
\hline Poor & \multirow{2}{*}{4.52} & \multirow{2}{*}{1.40} & \multirow{2}{*}{14.54} & \multirow{2}{*}{$0.011 *$} \\
\hline Good & & & & \\
\hline
\end{tabular}

times more stressful than appropriate workload. Meanwhile, social support was also significantly related to work stress with adjusted $\mathrm{OR}=4.52$ and $\mathrm{p}$ value $=0.011$ after other variables were controlled. It means that poor social support was 4.52 times higher in increasing work stress compared to the good one.

\section{DISCUSSION}

\section{Work Stress}

Work stress at the Health Office was stratified from no work stress to moderate work stress. Workers who did not experience work stress were the largest proportion with $86.67 \%$ of respondents. However, not experiencing work stress does not mean that respondents did not have complaints related to work stress at all. When viewed from the average score of work stress, it can be seen that the majority of respondents still had complaints related to work stress even though they had not reached the level that can be considered as work stress.

Complaints of work stress that rise among employees must be of concern to the managers, so they can be prevented before they become work stress at a higher level. Prevention can be carried out either with individual or organizational approaches (Ihsan, Ariffin and Dewi, 2018). Overall, these two approaches are the implementation of Manuaba's principal of job adjustment for men (Anggrianti, Kurniawan and Widjasena,2017). This principle must be carried out so that workers will not be burdened physically or psychologically when doing their job.

Work stress needs to be prevented so as not to interfere with the productivity of workers (Saleh, Russeng and Tadjuddin, 2020). Thus, the programs that has been planned by the Public Health Office Bogor Regency can be fully realized. Given that the Public Health Office is a government's health stakeholder, the realization of the established program is expected to improve the health status of the community.

\section{Work Stress Complaints during Pandemic}

The COVID-19 pandemic can affect both physical and mental health. Nowadays, COVID-19 pandemic is considered as a new source of stress in community all over the world. This pandemic situation can cause almost all types of mental disorders from mild to severe, and even can cause xenophobia and suicide (Riyadi et al., 2020). Among workers, pandemic could cause a lot of conflict and social inequity between organizations and workers. This would increase stress among workers and affect their psychological well-being (Damayanti and Mursid, 2021).

The results of this study showed an increase in the proportion of respondents who felt stress due to the pandemic compared to the respondents who have already experienced stress before the pandemic. A quarter of respondents also admitted that stress complaints were getting worse during the pandemic. However, this study did not analyze a direct correlation between work stress and the pandemic. Further research is expected to be able to analyze the correlation of these two. Thus, it will show whether the pandemic has a real impact on work stress or not.

\section{The Correlation between Individual Factors and Work Stress}

\section{Age}

The Respondents' age ranged between 21-58 years with most of respondents aged over 40 years old. There was no significant correlation between age and work stress of the respondents. This result is supported by previous study by Damayanti and Nawawinetu (2019) which stated that work stress was not related to age because it was more affected by the mental workload of workers. 
Age could be related to work stress due to the complexity of the problems faced by older workers (Gupita Bayuwega, Wahyuni and Kurniawan, 2016). Based on data from the Public Health Office, workers have already had a position with their respective duties and responsibilities. Instead of age, job demands were more influenced by the position held by the workers. The study of Klaiber et al. (2021) also mentioned that the frequency of COVID-19 stressors or the perceived severity of stressors did not occur significantly in different age groups. Therefore, either young or old workers share the same risk of experiencing work stress, especially in this COVID-19 pandemic.

\section{$\operatorname{Sex}$}

The majority of respondents were female workers. In this study, there was no correlation found between sex and work stress. Previous study also stated that the correlation between sex and work stress has not been confirmed due to the fact that both of the female and male workers actually have the same potential to be exposed to psychososcial hazards at the workplace (Padkapayeva et al., 2018).

In fact, women could suffer from stress more quickly due to higher prolactin the women have than men (Putri, 2020). However, based on observations, females and males did not experience different treatments in term of rights and obligations related to work. Every worker has the same opportunity to carry out his job with full capacity without being limited by gender. As civil servants, rights and obligations of workers have been regulated in the constitution on Civil Servants. In general, these rights and obligations are not affected by gender of the workers (Nurlitasari, 2017). Thus, there was no discrimination between women and men that could cause work stress, especially for female workers.

\section{Work Period}

Speaking of work period, this study did not find any significant correlation between the respondent's work period and work stress. This result supports a previous study which indicated that even though workers have worked for a long period of time, work stress could be avoided when the organizational environment supports all work processes so that feelings of satisfaction and comfort arise at work (Marshanty, Wardani and Sari, 2019).
Workers with a shorter work period were considered to have greater possibility for experiencing work stress. Lack of experience when facing various situations at their job could make workers feel more stressed at work. Work period can indeed determine the position held by workers. Workers in higher positions tend to have higher mental workloads than workers in lower positions (Mohamedkheir et al., 2016). However, based on the data of the Public Health Office, the position of workers was not only influenced by their long work period, but also by their education level. Therefore, there are workers with a short work period who have a higher position than workers with a longer working period. The results of observation also indicated that both new and old workers had already known what their job was and work accordance to their positions. New workers who tended to feel more stressed also no longer learned about their work problems, so they were not at risk of experiencing work stress (Juninda, 2019).

\section{Personality Type}

The majority of repondents were individuals with personality type A. Individuals with this kind of personality are known to be more aggressive and more ambitious than individuals with personality type B who are known to be more relaxed (Astuti, 2018). In this study, personality type was found not to have significant correlation with work stress. This result is consistent with a previous study that also showed no correlation between personality type and work stress because there was no significant difference between the proportion of workers with personality type $\mathrm{A}$ and the proportion of workers with personality type B experiencing work stress (Saraswati, 2017).

A person with personality type A can experience a higher level of stress when facing stressful situations (Nuzulawati, 2016). This happens because the characteristics of individuals with personality type A are result-oriented and do not know when to relax (Purwanti and Nurhayati, 2017). Based on interviews with respondents, it can be seen that workers' duties and responsibilities were given by not considering workers' personality type. Respondents also admitted that they did not really understand about their personality and just did their job without thinking about their personality type. Therefore, the stress experienced by workers tends not to be influenced by their personality type. 


\section{The Correlation between Work Factors and Work Stress}

\section{Physical Environment}

In general, respondents felt comfortable with their physical work environment. In this study, there was also no correlation found between physical work environment and work stress. Jundillah et al. (2017) who conducted a study on the causes of work stress among nurses in Konawe Kepulauan also showed that there was no correlation between the two because workers had already adapted to the conditions of the physical environment and work climate at their work place.

A good physical environment could actually increase positive mental strength (Monday and Sunday, 2020). Workers of the Public Health Office mostly worked indoors. Therefore, their working process was unlikely to be affected by bad temperature or uncomfortable physical environment. Based on observations, workers who felt uncomfortable could adjust their physical environment with the condition that is considered comfortable. Thus, they did not feel disturbed while doing their job,

\section{Career Development}

Most of respondents felt that they had poor career development. However, career development was found to be not significantly correlated with work stress. This result is supported by a previous study which stated that career development and work stress were not correlated because most of the workers were satisfied with the salary given (Purnama, Wahyuni and Ekawati, 2019).

The career development of civil servants is influenced by government policies, leadership attitudes, experience, level of education, and training (Usup, 2017). This has also been regulated in several constitutions (Pasiak, 2020). Employees of the Public Heath Office have equal opportunities to develop their careers according to the constitution on Civil Servants. Workers who do not have this kind of opportunity are only those who are about to retire because they are already at the final stage of their career development progress.

Even though career development has no correlation with work stress, workers should be given the opportunity to develop themselves and get promotions according to applicable regulations to prevent the possibilities of work stress (Dafinci, Meiliani and Kananlua, 2020).

\section{Role Conflict}

High role conflict was perceived by most of the respondents. In this study, there was no significant correlation between role conflict and work stress. A previous study also stated that there was no correlation between the two because workers had an education system that made them understand about their job at hand (Saraswati, 2017).

Role conflict is one of job demands dimensions that can become stressors at work (Lestari and Zamralita, 2018). Role conflict can occur due two contradictory orders received at the same time (Rifai, 2019). This can happen because inconstistent bureaucratic control mechanisms when workers have multiple jobs (Juwita and Arintika, 2018). Based on data of the Public Health Office, it is known that workers were divided into several sections, each of which had specific duties and functions. This could become a control for role conflict that might happen due to different tasks at the same time. Efforts to control role conflict as early as possible could prevent stress among workers (Rifai, 2019).

\section{Interpersonal Conflict}

Respondents who felt a high level of interpersonal conflict at work were more than respondents who felt the opposite. In this study, interpersonal conflict that was felt by respondents was found to be not significantly correlated with work stress. This result is consistent with the result of Benua, Lengkong and Pandowo (2019) study which conducted research among PT. Pegadaian Kanwil V Manado employees.

Interpersonal conflict could be categorized as a task conflict, which is differences of opinion among workers regarding work procedures, task responsibility, and resource delegation (Singh and Choudhary, 2018). Interpersonal confict management can involve organizational structure as one of its importants aspects. In the organizational structure, the unit leader is expected to be able to maintain interpersonal conflicts among workers as early as possible before they develop into much worse conflicts. Conflicts will be relatively easier and can be handled better when there are fewer people involved (Sudarmanto et al., 2021).

\section{Workload}

Workload was found to be significantly correlated with work stress, even being the most dominant variables affecting it. The result of this study is similar to a previous study which showed 
workload as one of the highest ranking stressors which could lead to higher levels of stress (Jiang et al., 2019).

Based on observations and discussion with employees, the Public Health Office has an important and active role for implementing local government programs in dealing with the COVID19 pandemic. The majority of workers at the Public Health Office were directly involved in handling the COVID-19 pandemic. Almost every work sector at the Public Health Office was affected by the COVID-19 pandemic. This situation demands hard work and quick work which could be additional workload for employees in the Public Health Office as a government institution at the health sector (Akbar, 2020). Additional workload has proven to be a dominant factor causing work stress (Shrivastava, 2020). Evidently, 33\% of respondents admitted that the pandemic has made them feel stressed when doing their job.

Although pandemic can cause an additional workload, there is also a possibility that over workload has occurred long before pandemic. In this study, workload refers to the subjective workload, namely workers' perception of their workload. This kind of perception could be the cause of work stress. Puspitasari's study on Air Traffic Control officers showed that the higher the perception of workload, the higher the level of work stress that can arise (Puspitasari and Kustanti, 2020). For this reason, it is necessary to adjust the workload with workers' ability to prevent the work stress (Shogunle, 2020).

Because this study used subjective workload assessment, every respondent, either directly or indirectly involved in handling the COVID-19 pandemic, could have some perception that they had high level of workload. An objective workload analysis is therefore needed so that the workloads given are truly in accordance with the workers' ability and not only depend on the subjective feelings of the workers (Wardanis, 2018).

\section{The Correlation between Factor Outside of Work and Work Stress}

\section{Non-work Acrivities}

Most of the respondents had high non-work ativities. However, the results showed that non-work activites were not significantly correlated with work stress. This result is consistent with a study by Lady, Susihono and Muslihati (2017) which stated that non-work activities were not correlated with work stress because respondents; non-work activities on that study were not at the level that could affect work stress. Imbalance between personal life and work can cause higher stress (Jaharuddin and Zainol, 2019). Inability to balance these two things will make workers have higher stress and depression (Piromon and Charoenarpornwattana, 2016). Based on the inteviews, it can be seen that respondents were able to manage time between non-work activities and job demands that must be completed even though they had so many activities outside of work. A good time management skill is a straight forward and low-cost method to minimize stressors and prevent workers from stress (Ravari et al., 2020).

\section{Social Suppport}

Another determinant of work stress found in this study was social support.This result was in line with a study on nurses in Grade 3 Inpatient Room Hospital X which also showed significant correlation between social support and work stress after other variables were controlled (Hamzens and Sofwati, 2017)

Based on interviews with the employees, social support was not only received from colleagues, but also came from the closest people of employees, such as friends, couples, and family. This kind of emotional support can help workers to release tension and reduce conflict. Lack of social support were associated with high stress (Lambert et al., 2017). On the other hand, good social support from a familiar figure is believed to be able to improve health status and reduce stress (Karina and Sodik, 2018).

\section{Determinants Related to Work Stress}

Workload and social support, which are aspects related to work stress, should be a concern of managers at the Public Health Office. High subjective workload has been shown to further increase work stress as well as poor social support. Efforts to adjust work capacity and workload as well as the development of a positive social work environment need to be carried out to implement the occupational safety and health at the workplace. Although they are considered to have a low frequency of work accidents and relatively small risk, offices such as Health Offices must also implement occupational safety and health (Nugroho, 2019). The implementation of occupational safety 
and health at the office is expected to improve employee performance (Suparman, 2017), especially in government offices where the employees are in charge of providing public services to the community.

\section{CONCLUSION}

Workloads and social support were significantly correlated with work stress. Workload was the most dominant variable affecting works stress. Prevention of work stress could be done by adjusting work capacity and workload as well as developing positive social work environment. Future research is expected to be able to assess work stress through medical diagnosis and further examine its relationship with the COVID-19 pandemic.

\section{ACKNOWLEDGEMENTS}

I would like to express my gratitude to the presence of God Almighty for such a blessing so that this study can be completed. I also thank my parents and my bestfriends for their support during this study. I also owe thanks to all employees of the Public Health Office Bogor Regency for their willingness to be respondents.

\section{REFERENCES}

Akbar, K. A. (2020) "Kepuasan Kerja Karyawan di Dinas Kesehatan Kabupaten X Provinsi Jawa Timur Saat Pandemi Covid-19," Jurnal Kesehatan, 11(3), pp. 336-344.

Anggrianti, S. M., Kurniawan, B. and Widjasena, B. (2017) "Hubungan Antara Postur Kerja Berdiri Dengan Keluhan Nyeri Kaki Pada Pekerja Aktivitas Mekanik Section Welding Di PT. X," Jurnal Kesehatan Masyarakat (Undip), 5(5), pp. 369-377.

Astuti, I. (2018) Hubungan Antara Kepribadian dengan Kepatuhan Minum Obat Anti TuberkulosisStudi Analitik Observasional Terhadap Penderita TB Paru di Rumah Sakit Islam Sultan Agung Semarang Periode Januari 2015-Maret 2017. Undergraduate Thesis. Semarang. Faculty of Medicine, Universitas Islam Sultan Agung.

Benua, M. G. N., Lengkong, V. P. K. and Pandowo, M. H. C. (2019) "Pengaruh Gaya Kepemimpinan, Konflik Interpersonal dan Mutasi Kerja Terhadap Stres Kerja Pada PT. Pegadaian (Persero) Kanwil V Manado," Jurnal EMBA: Jurnal Riset Ekonomi,
Manajemen, Bisnis dan Akuntansi, 7(3), pp. 3968-3707.

Dafinci, W. O., Meiliani, M. and Kananlua, P. S. (2020) "Studi Tentang Stres Kerja yang Berdampak Pada Kinerja Karyawan," The Manager Review, 2(2), pp. 32-51.

Damayanti, H. and Mursid, A. (2021) "Pengaruh Occupational Stress dan Psychological Contract terhadap Work Engagement Melalui Psychological Well Being di Saat Pandemi Covid 19 (Studi pada Karyawan KCP Bank Jateng Pasar Johar)," Magisma: Jurnal Ilmiah Ekonomi dan Bisnis, 9(1), pp. 12-26.

Damayanti, R. and Nawawinetu, E. D. (2019) "Determinant Factors of Work Stress among Teaching and Non Teaching Staff in Indonesia," Indian Journal of Public Health Research \& Development, 10(3), pp. 307-311.

Gupita Bayuwega, H., Wahyuni, I. and Kurniawan (2016) "Faktor-Faktor yang Berhubungan dengan Stres Kerja pada Anggota Polisi Satuan Reserse Kriminal Polres Blora," Jurnal Kesehatan Masyarakat (Undip), 4(4), pp. 2356-3346.

Hamzens, F. and Sofwati, I. (2017) Faktor-Faktor yang Berhubungan dengan Stres Kerja Pada Perawat di Ruang Rawat Inap Kelas III RS X Jakarta Tahun 2017. Undergraduate Thesis. Jakarta: Faculty of Medicine and Health Science, Universitas Islam Negeri Syarif Hidayatullah.

Hasanah, L., Rahayuwati, L. and Yudianto, K. (2020) "Sumber Stres Kerja Perawat Di Rumah Sakit," Jurnal Persatuan Perawat Nasional Indonesia (JPPNI), 3(3), pp. 111-128.

Health \& Safety Executive (2018) Work Related Stress, Depression or Anxiety Statistics in Great Britain, 2018. London: Health and Safety Executive.

Ihsan, A. A., Ariffin, Z. and Dewi, M. S. (2018) "Pengaruh Stres Kerja Dan Beban Kerja Terhadap Turnover Intention (Studi Pada PT. Bank Syariah Mandiri, Cabang Banjarmasin)," JTAM Jurusan Manajemen FEB ULM: JIMI, 1(2), pp. 152-166.

Jaharuddin, N. S. and Zainol, L. N. (2019) "The Impact of Work-Life Balance on Job Engagement and Turnover Intention," The South East Asian Journal of Management, 13(1), pp. 106-118.

Jiang, Y. et al. (2019) "Prevalence of Stress And Its Determinants among Residents Enrolled in China Standardized Training Program For Resident Doctor (C-STRD) Program: A Cross-Sectional Study," PLoS One, 14(1), p. e0207258. 
Jundillah, Z. N. et al. (2017) "Analisis Kejadian Stres Kerja pada Perawat di Kabupaten Konawe Kepulauan Tahun 2017,” Jimkesmas: Jurnal Ilmiah Mahasiswa Kesehatan Masyarakat, 2(6), pp. 1-11.

Juninda, M. (2019) Faktor Yang Berhubungan Dengan Stres Kerja Pada Pekerja Di Pt. Pupuk Iskandar Muda Aceh Tahun 2019. Undergraduate Thesis. Medan. Faculty of Public Health, Institut Kesehatan Helvetia.

Juwita, K. and Arintika, D. (2018) "Dampak Konflik Peran terhadap Stres dan Kepuasan Kerja Karyawan PT. Jombang Intermedia Press (Jawa Pos Radar Jombang)," Jurnal Manajemen Indonesia, 18(2), pp. 105-115.

Karina, Z. and Sodik, M. A. (2018) Pengaruh Dukungan Sosial Terhadap Kesehatan. OSF Preprints.

Klaiber, P. et al. (2021) "The Ups and Downs of Daily Life During COVID-19: Age Differences in Affect, Stress, and Positive Events," The Journals of Gerontology: Series B. Oxford University Press US, 76(2), pp. e30-e37.

Lady, L., Susihono, W. and Muslihati, A. (2017) "Analisis Tingkat Stres Kerja dan Faktor-Faktor Penyebab Stres Kerja pada Pegawai BPBD Kota Cilegon," Journal Industrial Servicess, 3(1b), pp. 191-197.

Lambert, E. G. et al. (2017) "Exploring The Association Between Different Types of Social Support with Role Stress, Work-Family Conflict, and Turnover Intent among Private Prison Staff," Journal of Applied Security Research, 12(2), pp. 203-223.

Lestari, W. and Zamralita, Z. (2018) "Gambaran Tuntutan Pekerjaan (Job Demands) dan Dukungan Pekerjaan (Job Resources) pada Pegawai Institusi X DKI Jakarta," Jurnal Muara Ilmu Sosial, Humaniora, dan Seni, 1(2), pp. 134-143.

Lutfida, T. (2020) Dinamika Stress Masa Pandemi. PsyArXiv.

Marshanty, Y. A., Wardani, I. A. K. and Sari, J. D. E. (2019) "Hubungan Beban Kerja Mental, Masa Kerja dan Usia terhadap Kejadian Stres pada Pekerja Perusahaan Akuakultur di Banyuwangi," Journal of Community Mental Health and Public Policy, 2(1), pp. 1-11.

Mohamedkheir, R. A. et al. (2016) "Occupational Stress Among Nurses Working in Intensive Care Units in Public Hospitals of Khartoum State, Sudan 2016," American Journal of Health Research, 4(6), pp. 166-171.
Monday, I. F. and Sunday, I. E. (2020) “Occupational Stress, Physical Work Environment and Psychological Well-Being: The Experience of Bank Employees," Gender \& Behaviour. IFE Centre for Psychological Studies, 18(2), pp. 15382-15389.

Nugroho, B. Y. S. (2019) Pentingnya Penerapan K3 di Perkantoran. Semarang: Informasi Kesehatan Udinus.

Nugroho, M. A. (2021) Pengaruh Beban Kerja dan Kecerdasan Spiritual terhadap Burnout pada Dosen dengan Tugas Tambahan. Undergraduate Thesis. Surabaya. Fakultas Psikologi dan Ilmu Kesehatan. UIN Sunan Ampel.

Nurlitasari, N. (2017) Psychological Capital Pegawai Kontrak Ditinjau dari Jenis Kelamin di Dinas Cipta Karya dan Tata Kota Samarinda. Doctoral Dissertation. Semarang. Faculty of Science Education. Universitas Negeri Semarang.

Nuzulawati, M. T. (2016) "Hubungan antara Kepribadian Tipe A dengan Stres Kerja pada Guru SMK Abstrak," Jurnal Proyeksi, 11(1), pp. 15-23.

Padkapayeva, K. et al. (2018) “Gender/Sex Differences in the Relationship between Psychosocial Work Exposures and Work and Life Stress," Annals of Work Exposures and Health. Oxford University Press, 62(4), pp. 416-425.

Pasiak, P. (2020) "Pengembangan Karier Aparatur Sipil Negara (ASN) Berdasarkan Sistem Merit Menurut Undang-Undang Nomor 5 Tahun 2014 Tentang Aparatur Sipil Negara pada Pemerintah Kota Bitung," Lex Administratum, 8(2), pp. 31-42.

Peristianto, S. V. (2021) "Religiusitas Tenaga Medis dalam Persiapan New Normal Setelah Masa Pandemi Covid-19," Psisula: Prosiding Berkala Psikologi, 2, pp. 388-400.

Pirom-on, P. and Charoenarpornwattana, P. (2016) "Work-Life Balance In A Selected Surgery Clinic In Chonburi," E - Proceeding International Conference in Innovative Business and Entrepreneurship 2017, 2(1), pp. 148-155.

Purnama, K. W., Wahyuni, I. and Ekawati, E. (2019) "Faktor-Faktor yang Berhubungan dengan Stres Kerja pada Pegawai Negeri Sipil Badan Penanggulangan Bencana Daerah (BPBD) Kota Semarang," Jurnal Kesehatan Masyarakat (e-Journal) , 7(4), pp. 246-253.

Purwanti, D. and Nurhayati, M. (2017) "Pengaruh Iklim Organisasi dan Tipe Kepribadian terhadap Stres Kerja dan Perilaku Kewargaan (Studi pada 
Karyawan Klinik Laboratorium Prodia Cabang Menteng, Jakarta)," Jurnal Manajemen, 20(2), pp. 293-309.

Puspitasari, M. D. and Kustanti, E. R. (2020) "Hubungan Antara Persepsi Beban Kerja dengan Stress Kerja pada Air Traffic Controller di Perum LPPNPI Airnav Indonesia Cabang Madya Surabaya," Jurnal Empati, 7(1), pp. 113-118.

Putri, F. J. (2020) Faktor-faktor yang Berhubungan dengan Stres Kerja pada Perawat di Rumah Sakit: Sebuah Tinjauan Sistematis. Undergraduate Thesis. Palembang: Public Health Study Program, STIK Bina Husada Palembang.

Ravari, A. K. et al. (2020) "The Effectiveness of A Time Management Workshop on Job Stress of Nurses Working in Emergency Departments: An Experimental Study," Journal of Emergency Nursing, 46(4), pp. 548.e1-548.e11.

Reppi, B., Sumampouw, O. J. and Lestari, H. (2020) "Faktor-faktor Risiko Stres Kerja pada Aparatur Sipil Negara," Sam Ratulangi Journal of Public Health, 1(1), pp. 33-39.

Rifai, R. P. (2019) "Pengaruh Konflik Peran dan Ambiguitas Peran Terhadap Kinerja Karyawan dengan Stres Kerja Sebagai Variabel Intervening Pada PT. Bank SulutGo," Jurnal Riset Bisnis dan Manajemen, 7(4), pp. 339-350.

Riyadi, A. et al. (2020) Dinamika Pendekatan Dalam Penangananan Covid-19. Edited by M. Nasrudin. Pekalongan: Penerbit NEM

Saleh, L. M., Russeng, S. S. and Tadjuddin, I. (2020) "Manajemen Stress Kerja: Sebuah Kajian Keselamatan dan Kesehatan Kerja dari Aspek Psikologis pada ATC," Yogyakarta: Deepublish.

Saraswati, M. (2017) Faktor-Faktor Yang Berhubungan Dengan Stress Kerja Pada Teknisi Pesawat Terbang Unit Base Maintenance Di PT. X Tahun 2017. Undergraduate Thesis. Jakarta. Faculty of Medicine and Health Science, Universitas Islam Negeri Syarif Hidayatullah.

Sedana, I. G. N. A. (2018) Hubungan Tingkat Stres dengan Perilaku Pencegahan Stroke Pada Klien Hipertensi di Puskesmas I Denpasar Timur Kota
Denpasar Tahun 2018. Diploma Thesis. Denpasar. Nursing Major, Poltekkes Denpasar.

Shogunle, M. D. (2020) “Job Stress and Employees' Performance: Evidence from Manufacturing Industries in Lagos, Nigeria," Hallmark University Journal Of Management \& Social Sciences, 2(2), pp. 36-49.

Shrivastava, A. (2020) "Identifying and Analyzing Occupational Stress Factors among Faculty of Autonomous Colleges in Madhya Pradesh," Academic Leadership (Online Journal), 21(04).

Sinclair, R. R. et al. (2020) "Occupational Health Science in the Time of COVID-19: Now more than Ever," Occupational Health Science, 4(1), pp. 1-22.

Singh, T. and Choudhary, S. (2018) "Organisational Justice, Experiencing Interpersonal Conflict and Employee Engagement: A Moderated Mediation Analysis," Journal of Organisation and Human Behaviour. Publishing India Group, 7(1), pp. $1-10$.

Sorongan, J., Suoth, L. F. and Boky, H. (2018) "Hubungan Antara Stres Kerja dan Upah dengan Produktivitas Kerja pada Pegawai di Dinas Kesehatan Kota Manado," Jurnal Kesmas, 7(5), pp. 1-8.

Sudarmanto, E. et al. (2021) Manajemen Konflik. Edited by R. Watrianthos. Medan: Yayasan Kita Menulis.

Suparman, H. (2017) "Pentingnya Penerapan Program K3 Perkantoran dalam Meningkatkan Kualitas Kinerja Sekretaris," Konferensi Nasional Ilmu Sosial dan Teknologi, 1(1), pp. 613-618.

Usup, H. (2017) "Pengembangan Karier Aparatur Sipil Negara, Pada Dinas Perhubungan Komunikasi Dan Informatika Kabupaten Bolaang Mongondow," Jurnal Administrasi Publik, 3(046), pp. 1-8.

Wardanis, D. T. (2018) “Analisis Beban Kerja Tenaga Rekam Medis Rumah Sakit Bedah Surabaya Menggunakan Metode FTE," Jurnal Administrasi Kesehatan Indonesia, 6(1), pp. 53-60. 